\title{
THE RESEARCH OF PROJECT MATURITY IN MINING SERVICE ENTERPRISES IN POLAND
}

\author{
Jarosław JAMROZY ${ }^{1}$, Krzysztof WODARSKI ${ }^{2 *}$, Barbara SORYCHTA-WOJSCZYK ${ }^{3}$ \\ ${ }^{1}$ Remagum Sp. z o.o. Sp.k., Mysłowice; jj.jamrozy@gmail.com \\ ${ }^{2}$ Silesian University of Technology, Faculty of Organization and Management, Zabrze; \\ krzysztof.wodarski@polsl.pl., ORCID: 0000-0002-4725-1064 \\ ${ }^{3}$ Silesian University of Technology, Faculty of Organization and Management, Zabrze; \\ Barbara.Sorychta-Wojsczyk@polsl.pl., ORCID: 0000-0002-5237-8908 \\ * Correspondence author
}

\begin{abstract}
Project maturity is the ability of an organisation to effectively select a project portfolio in such a way that the execution of these projects contributes to the objectives and strategy of the organisation and the ability to apply professional project management techniques and tools in order to achieve high quality project products, repeatability of successes and avoid failure in forthcoming projects. The article presents the results of preliminary survey research aiming to assess the degree of maturity in project management in the scope of methods and tools, human resources, environment and knowledge management. The research was conducted in mining service enterprises in Poland.
\end{abstract}

Keywords: project management, project maturity, mining service enterprise.

\section{Project maturity of an organisation}

The maturity of an organisation can be regarded as the organisation's ability to effectively manage projects. The Project Management Institute may also define an organisation's project maturity as the ability to select projects whose implementation leads to the achievement of the organisation's objectives (PMI, 2008). According to the Software Engineering Institute (OGC, 2007), this is the level of development of an organisation in relation to project management or the organisation's willingness to implement projects. An interesting definition is given by J. Schlichter (Wyrozębski, Juchniewicz, Matelski, 2012), treating this concept as the ability of an organisation to identify project success factors and prevent project problems. Therefore, in literature on the subject, the term "project maturity of an organisation" is defined in a number of different ways. Many definitions emphasise the different criteria that an organisation has to meet in order to be defined as mature. This means that the process of 
reaching maturity is related to improving skills until they are fully achieved in various dimensions: economic, social or biological (Juchniewicz, 2009).

Kerzner (Kerzner, 2005) defines maturity as "the degree of development of a system and processes that are inherently repetitive and likely to be successful in future projects. However, the repeatability of systems and processes does not guarantee success, but only increases its chances". This signifies that as the level of project maturity increases, the organisation achieves a higher degree of excellence, reflecting its development.

Project maturity is an organisation's ability to effectively select a project portfolio in such a way that the implementation of these projects supports the organisation's objectives and strategy, as well as its ability to use professional project management techniques and tools in order to achieve high quality project products, repeatability of successes and avoid failures in upcoming projects (Juchniewicz, 2012).

Project Management Maturity Models are used to measure an organisation's project maturity. The maturity model is defined as a structured set of elements describing specific aspects of an organisation's maturity, which also helps to define and understand processes in the organisation. The maturity model often includes a common terminology, a common vision and structure for setting priorities for improvement actions. The most common universal models nowadays are:

- Organisational Project Management Maturity Model (OPM3) (PMI, 2008),

- Prince 2 Maturity Model (OGC, 2007),

- Project Management Maturity Model (PMI, 2008),

- Project Management Process Maturity Model - PM2 (PMI, 2008),

- Project Management Maturity Model - ProMMM (Kerzner, 2005),

- Strategic Project Management Maturity Model (Schott, Campana, 2005; Grundy, Brown, 2002).

Project Maturity Models can be divided into two groups. The first group of models (which includes, among others, Prince2 Maturity Model, Kerzner Project Management Maturity Model, OGC Project Management Maturity Model and PM Solutions Project Management Maturity Model) involves assigning an organisation to one of several levels of project maturity (usually five), and these are of a static and dynamic nature. The second group comprises models that do not determine the level of maturity of the organisation but use them to assess individual areas of project management in the organisation. The result of the assessment is mostly expressed in percentages and points. This group includes the Organisational Project Management Maturity Model (OPM3) and all other related models, most often developed by consulting companies based on OPM3.

For the purpose of this article, the model proposed by Spałek (Spałek, 2013) was used, in which the degree of maturity in project management should be assessed in the following four key areas: 
- methods and tools (M),

- human resources (L),

- the project environment (S),

- knowledge management (W).

Five levels of maturity in project management have also been identified, namely (Table 1):

- level 1 - Initial,

- level 2 - Standardisation,

- level 3 - Applications/Usage,

- level 4 - Systemic management,

- level 5 - Self-improvement.

Table 1.

Levels of project maturity in particular areas of measurement

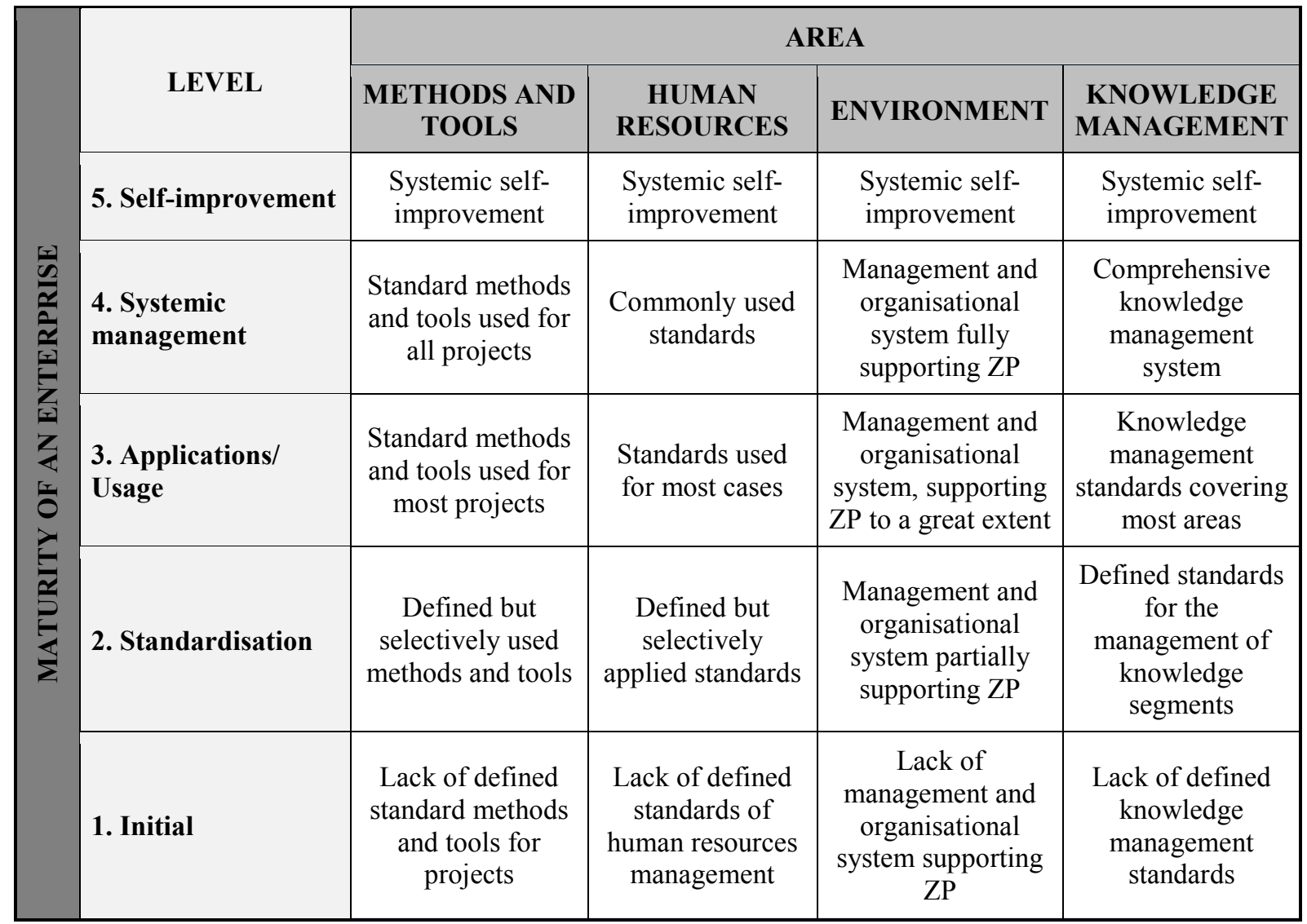

Source: Spałek, 2013. 


\section{The characteristics of mining service enterprises in Poland}

The transformation of the Polish economy initiated in 1989 also affected the hard coal mining sector. The period of transformation of the Polish economy towards a market economy began the process of restructuring the hard coal mining industry. One of the restructuring effects was the separation of organisational units from the structures of mines, which performed previously selected functions in the scope of implementation of basic, preparatory, supporting and accompanying processes of hard coal production. These entities were transformed into commercial law companies, and their activity involved the provision of services to hard coal mines on an outsourcing basis. Currently, these services are provided on the basis of orders for the execution of specialist mining works. Presently, the share of mining service enterprises in the structure of the hard coal production process is significant. A study of the documentation of tenders for coal enterprises in 2018 showed that mining service enterprises carry out orders at every level of partial processes, understood as a technological process which must be carried out in order to produce coal (Fig. 1). Mining service enterprises in Poland provide their services on the basis of orders for the execution of specialist access, preparatory, reinforcement, decommissioning and maintenance works. It can be said that these orders have the characteristics of projects, which results from the specificity of mining activity, which is characterised by constantly changing mining and geological conditions occurring in mines and the movement of elements of the production process within the rock mass. However, the complexity of these projects results from the nature and scope of the works and from the level of involvement of the company's resources.

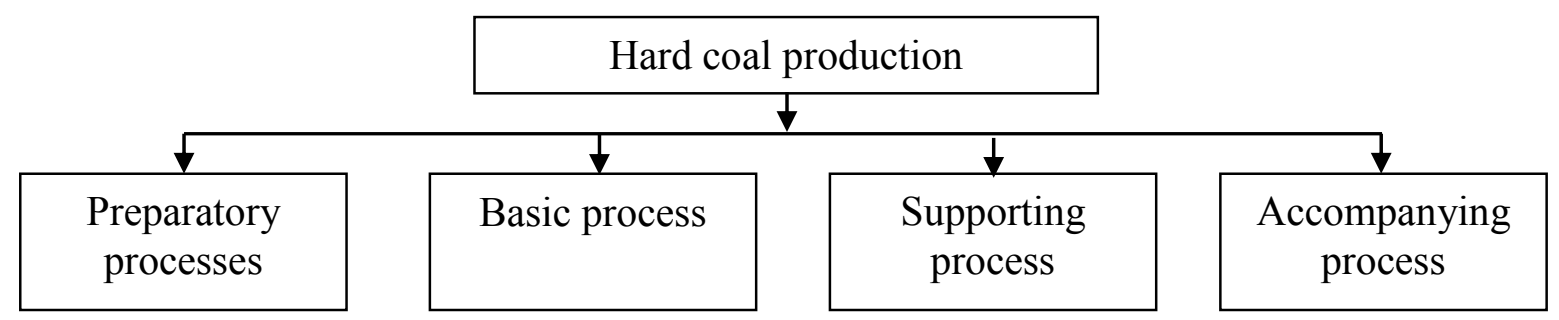

Figure 1. Technological processes in coal production. Source: own elaboration.

Research shows that in mining service enterprises, the number of projects carried out for mining companies and their value in recent years has been showing an upward trend. A characteristic feature of mining service enterprises is the diversity of projects carried out. In the context of preparatory processes, there are projects related to:

- creating opening-out or preparatory headings,

- maintaining the work ability and the condition specified in the OHS regulations of the opening-out or preparatory headings,

- modernisation of opening-out or preparatory headings. 
The projects carried out in the basic processes are related to:

- exploitation of mine walls (reinforcement of walls, exploitation of walls, modernisation of technical equipment of walls, maintenance of walls, decommissioning),

- execution of tasks in the Mechanical Coal Processing Plant.

Mining service enterprises execute large-scale projects in support processes. These include, for example, projects for mines related to:

- ventilation (construction of ventilation dams),

- safety of work (making holes and shafts for methane drainage, building methane drainage pipelines),

- backfilling, compressed air,

- transport (construction, maintenance, operation of haulage conveyors, material handling),

- power economy (operation of switchgears).

Accompanying processes, such as mining damage repair, modernisation, construction and maintenance of environmental protection facilities, are increasingly being implemented through projects outsourced to service companies.

In 2018, the number of projects implemented by 26 Polish mining service enterprises in the Polish coal mining industry amounted to 234 in Poland, including 185 projects which were the basis for the implementation of preparatory processes and 49 for basic processes (Figure 2). The value of projects executed by mining service enterprises in 2018 exceeded PLN 1 billion.

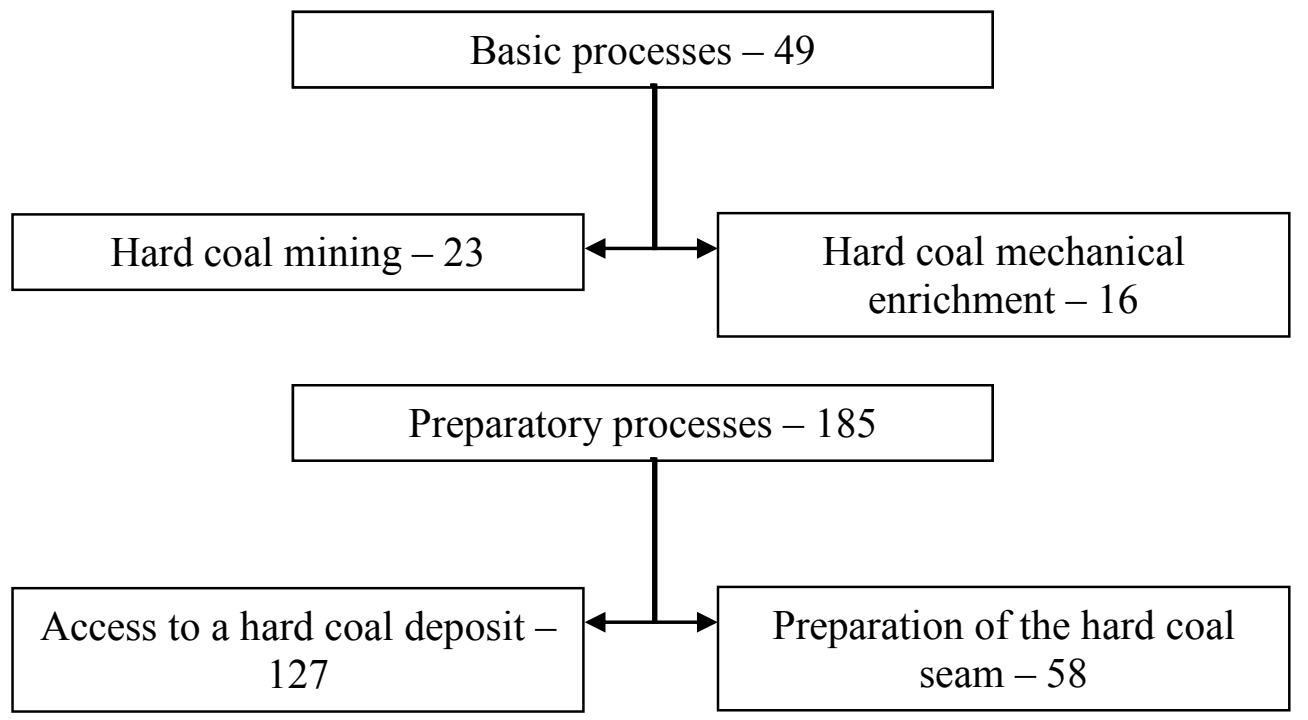

Figure 2. Number of projects executed in particular coal production processes. Source: own elaboration.

The results of the research presented suggest that the activities of the mines are highly dependent on mining service enterprises. The projects related to the construction of headings alone account for about $30 \%$ of the total number of mining works in Polish mines (Table 2). 
Table 2.

Preparatory work-drifts in the years 2015-2018

\begin{tabular}{|l|c|c|c|c|}
\hline & $\mathbf{2 0 1 5}$ & $\mathbf{2 0 1 6}$ & $\mathbf{2 0 1 7}$ & $\mathbf{2 0 1 8}$ \\
\hline length of mine workings with production - total [mb] & 288492 & 272829 & 261539 & 257597 \\
\hline $\begin{array}{l}\text { including the length of mine workings reported by the } \\
\text { enterprises * [mb] }\end{array}$ & 239190 & 216776 & 199413 & 190640 \\
\hline $\begin{array}{l}\text { including the length of mine workings made by external } \\
\text { enterprises [mb] }\end{array}$ & 64819 & 57761 & 57660 & 47004 \\
\hline share of mine workings made by external enterprises [\%] & 27.1 & 26.6 & 28.9 & 24.7 \\
\hline
\end{tabular}

Source: own elaboration based on data sent to the IDA Katowice branch by coal enterprises, which are obliged to submit such information.

Mining service enterprises have begun to use modern solutions for a better and more effective execution of these projects. Comprehensive coordination of processes is crucial for the simultaneous management of many projects, from the analysis of the project environment (including stakeholders) and optimal resource planning to a unified systemic approach to quality, project risk and finance management. Project management in a multi-project environment is not an easy task, hence it often does not bring about the expected results. Therefore, it is critical to adjust the organisational system of the company in such a way as to efficiently manage not only a single project, but also the entire portfolio of projects.

A further question arises whether mining service enterprises in Poland are well prepared for project management in a multi-project environment. This is a matter of the maturity of these organisations in relation to project management. With this in mind, research was conducted in the field of project management maturity assessment in mining service enterprises. They included survey research and unstructured interviews with the management staff.

The article presents the results of these studies. The research was conducted on the basis of a questionnaire prepared for this purpose. The questionnaire prepared for the survey contained 35 questions in four areas, i.e. human resources, methods and tools, environment and knowledge management.

\section{Methods}

The aim of the research was to assess the maturity level in project management of mining service enterprises in Poland. In mainly aims at obtaining answers to the following research questions:

1. Do mining service enterprises have a defined set of standards and project management tools?

2. Do they use these tools in project management? 
3. Do mining service enterprises build systems to measure the performance of project managers?

4. Do mining service enterprises have an adequate organisational structure to support project management?

5. Is intellectual capital (knowledge and experience) accumulated, stored and used in mining service enterprises in subsequent projects?

For this study, 26 mining service enterprises that operate on the Polish market were invited to participate in the questionnaire, of which 19 enterprises (which accounts for $73 \%$ of the total population) took part, including 4 large, 11 medium and 4 small enterprises. The definition of small and medium enterprises was adopted as the Act on Freedom of Economic Activity of 2 July 2004 (Articles 105 and 106 of the Journal of Laws, No. 173, item 1807, Articles 103-110 have been in effect since 1 January 2005). Enterprises which exceed the statutory thresholds (turnover, number of employees, ownership structure) are classified as large.

Mining service enterprises that participated in the research carried out the following number of projects:

- small mining service enterprises - executed 12 projects, all of which were related to preparatory processes (i.e. maintaining the work ability of the opening-out and preparatory headings, as well as the modernisation of headings, in accordance with OHS regulations);

- medium mining service enterprises - executed 70 projects, including 18 basic projects (i.e. 10 projects related to extraction processes, 8 projects related to processes at the processing plant), 52 preparatory projects (i.e. making 22 preparatory and opening-out headings, modernisation of 16 headings and maintenance of 14 headings);

- large mining service enterprises - executed 45 projects, including 10 basic projects (i.e. 5 projects related to extraction processes, 5 projects related to the processing plant), 35 preparatory projects (10 projects related to the creation of preparatory and openingout headings, 10 projects related to the modernisation of headings and 15 projects related to the maintenance of headings).

With regard to the number of projects executed in one year, it can be concluded that the mining service enterprises in Poland are focused on project management.

\section{Results}

The results of the survey research carried out among mining service enterprises in Poland in relation to the following areas - methods and tools, human resources, environment and knowledge management - are presented in Tables 3 to 6 . 


\section{Discussion}

The discussion of the survey research results was conducted for the areas of methods and tools, human resources, environment and knowledge management.

\section{The area of methods and tools}

The survey research showed that $90 \%$ of the enterprises participating in the research (i.e. 17 mining service enterprises) have an established project management policy, including all medium and large mining service enterprises. This policy is established in $50 \%$ of the small mining service enterprises. The examined enterprises have defined methods and tools and apply them in most projects; this is the case in $74 \%$ of enterprises. However, it should be noted that $100 \%$ of medium and large enterprises use methods and tools for project management and adapt them to the needs of individual projects (i.e. $45 \%$ of medium and $75 \%$ of large enterprises use project management methods and tools). However, only $25 \%$ of small mining service enterprises use project management methods and tools. All surveyed medium and large enterprises have a common, defined language to describe the activities and results in the project, and only $25 \%$ of small enterprises have a common and well-defined language to describe the activities and results in the project.

In the scope of methods and tools, the project maturity of medium and large mining service enterprises should be evaluated at level 3 (Applications/Usage), which implies the use of standard methods and tools in most projects. However, for small mining service enterprises, the project maturity here is at level 1 (Initial). In other words, the small mining service enterprises do not have defined standard methods and tools for project management.

\section{The area of human resources}

The conducted research indicates that $84 \%$ of enterprises have a quality management system certified by an external organisation, i.e. all medium and large enterprises, but only one small mining service enterprise. With regard to the existence of qualified project managers, $79 \%$ of enterprises have such employees, while all large enterprises and $91 \%$ of medium enterprises, and only $25 \%$ of small enterprises, have such employees. In $92 \%$ of large enterprises, there are systems ensuring adequate competences and professional development of managers and people assigned to projects, while in medium and small mining service enterprises, this is only true in $45 \%$ and $25 \%$ of cases, respectively.

In small mining service enterprises, the project maturity was assessed at level 1 (Initial). This is due to the fact that they do not have defined standards of human resources management. In medium mining service enterprises, the project maturity was assessed at level 2 (Standardisation). This means the application of selectively defined standards. In large mining service enterprises, the project maturity was assessed at level 3 (Applications/Usage), where human resources management standards are applied in most projects. 
Table 3.

The results of research regarding the area of methods and tools in mining service enterprises in Poland

\begin{tabular}{|c|c|c|c|c|c|c|c|c|c|c|c|c|c|c|c|c|c|c|c|c|c|c|c|c|c|c|c|c|}
\hline \multirow[b]{3}{*}{ No. } & \multirow[b]{3}{*}{ Question } & \multicolumn{9}{|c|}{ Small enterprises } & \multicolumn{9}{|c|}{ Medium enterprises } & \multicolumn{9}{|c|}{ Large enterprises } \\
\hline & & \multicolumn{9}{|c|}{ Answers } & \multicolumn{9}{|c|}{ Answers } & \multicolumn{9}{|c|}{ Answers } \\
\hline & & $\stackrel{\infty}{\infty}$ & Z & 㐫 & 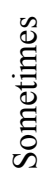 & 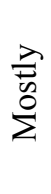 & 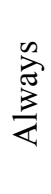 & $\stackrel{\infty}{2}$ & Z & 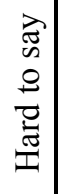 & $\stackrel{\infty}{\infty}$ & $\stackrel{\circ}{Z}$ & $\begin{array}{l}\dot{0} \\
\stackrel{0}{0} \\
\dot{0}\end{array}$ & 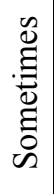 & $\begin{array}{l}\vec{\nabla} \\
\text { 离 } \\
\sum_{2}^{2}\end{array}$ & 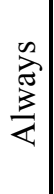 & $\stackrel{\infty}{\infty}$ & $\stackrel{\circ}{z}$ & 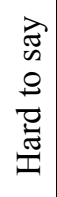 & $\stackrel{\infty}{\infty}$ & z & $\begin{array}{c}\dot{\bar{d}} \\
\overrightarrow{0} \\
\overline{0}\end{array}$ & 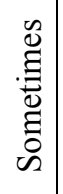 & 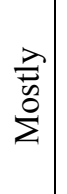 & 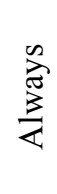 & $\infty_{\infty}^{\infty}$ & z & 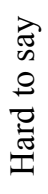 \\
\hline 1. & $\begin{array}{l}\text { The enterprise has an established project } \\
\text { management policy }\end{array}$ & 2 & 2 & & & & & & & & 11 & & & & & & & & & 4 & & & & & & & & \\
\hline 2. & $\begin{array}{l}\text { Appropriate scheduling tools are used in the } \\
\text { projects }\end{array}$ & 1 & 3 & & & & & & & & 9 & 2 & & & & & & & & 4 & & & & & & & & \\
\hline 3. & $\begin{array}{l}\text { The enterprise possesses and applies a risk } \\
\text { management system in its projects }\end{array}$ & & & & 3 & 1 & & & & & & & & & 5 & 6 & & & & & & & & & 4 & & & \\
\hline 4. & $\begin{array}{l}\text { The enterprise is able to define how the } \\
\text { success of a project will be measured }\end{array}$ & & & & 2 & 2 & & & & & & & & & 5 & 6 & & & & & & & & & 4 & & & \\
\hline 5. & $\begin{array}{l}\text { The enterprise measures the business value } \\
\text { of the project for the organisation }\end{array}$ & & & 1 & 1 & 2 & & & & & & & & & 3 & 8 & & & & & & & & 1 & 3 & & & \\
\hline 6. & $\begin{array}{l}\text { The enterprise utilises defined processes in } \\
\text { projects in order to allocate human } \\
\text { resources and their records }\end{array}$ & & & 1 & 1 & 2 & & & & & & & & & 6 & 5 & & & & & & & & & 4 & & & \\
\hline 7. & $\begin{array}{l}\text { Standard, well-defined techniques and tools } \\
\text { are customised to meet the demands of } \\
\text { individual projects }\end{array}$ & & & 1 & 2 & 1 & & & & & & & & & 6 & 5 & & & & & & & & 1 & 3 & & & \\
\hline 8. & $\begin{array}{l}\text { The enterprise collects standardised metrics } \\
\text { from the projects }\end{array}$ & & & 3 & & 1 & & & & & & & & & 8 & 3 & & & & & & & & & 4 & & & \\
\hline
\end{tabular}


Cont. table 3.

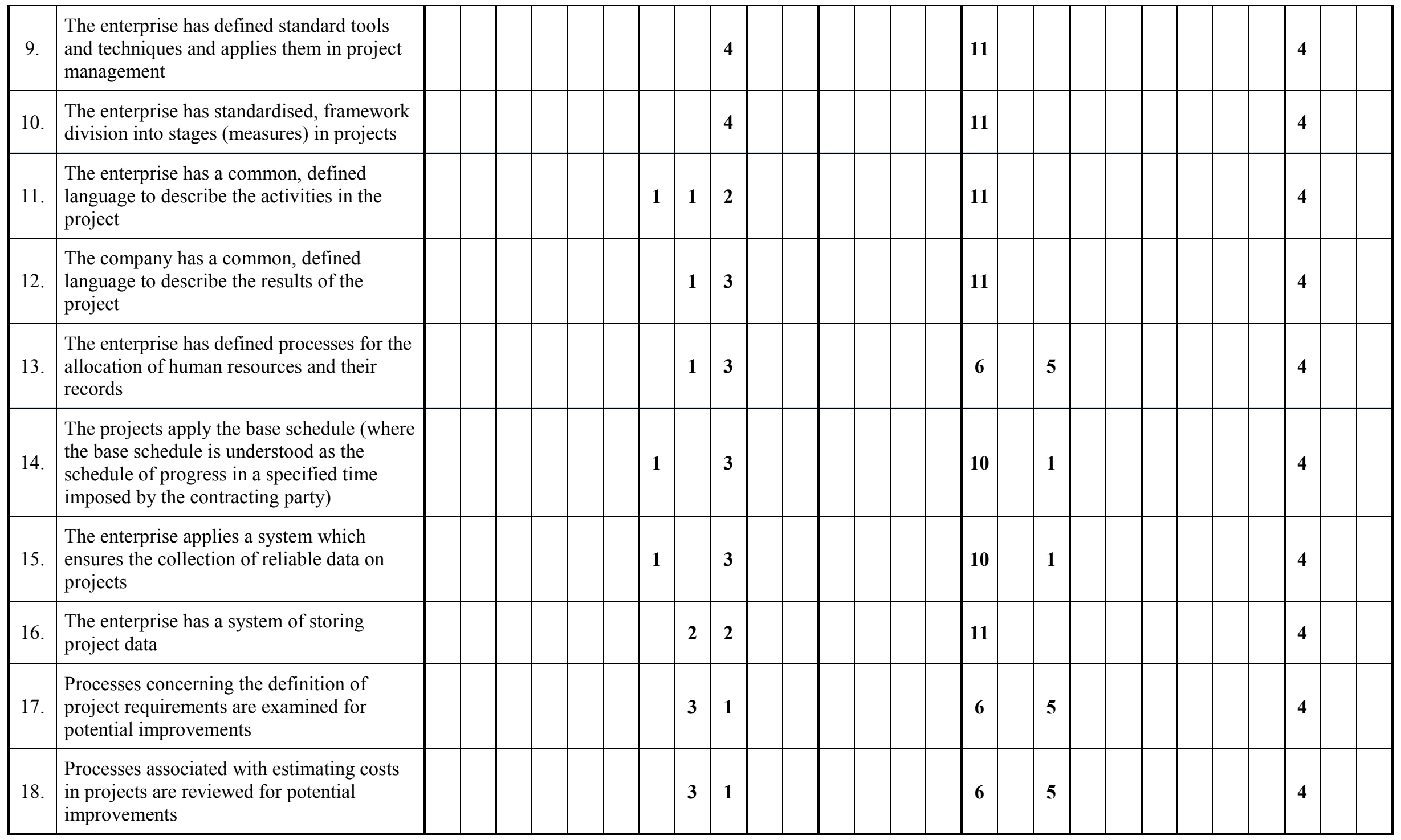

Own elaboration. 
Table 4.

The results of research regarding the area of human resources in mining service enterprises in Poland

\begin{tabular}{|c|c|c|c|c|c|c|c|c|c|c|c|c|c|c|c|c|c|c|c|c|c|c|c|c|c|c|c|c|}
\hline \multirow[b]{3}{*}{ No. } & \multirow[b]{3}{*}{ Question } & \multicolumn{9}{|c|}{ Small enterprises } & \multicolumn{9}{|c|}{ Medium enterprises } & \multicolumn{9}{|c|}{ Large enterprises } \\
\hline & & \multicolumn{9}{|c|}{ Answers } & \multicolumn{9}{|c|}{ Answers } & \multicolumn{9}{|c|}{ Answers } \\
\hline & & 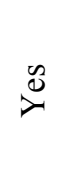 & $\stackrel{\circ}{z}$ & 岕 & 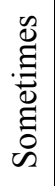 & $\stackrel{\vec{t}}{\sum^{0}}$ & 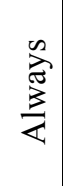 & $\overbrace{}^{\infty}$ & z & 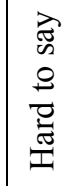 & $\stackrel{\infty}{\infty}$ & $\stackrel{\circ}{z}$ & 离 & 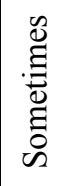 & $\frac{\lambda}{\vec{w}^{2}}$ & 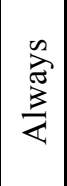 & $\stackrel{0}{2}$ & $\stackrel{\circ}{z}$ & 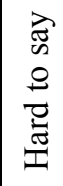 & $\stackrel{0}{\nu}$ & z & $\begin{array}{l}\dot{0} \\
\dot{0} \\
\dot{z}\end{array}$ & 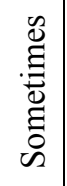 & $\stackrel{\vec{\forall}}{\overrightarrow{v^{\circ}}}$ & 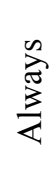 & $\stackrel{\infty}{\infty}$ & $\stackrel{\circ}{z}$ & 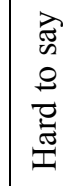 \\
\hline 1. & $\begin{array}{l}\text { The enterprise has a quality } \\
\text { management system certified by } \\
\text { an external organisation }\end{array}$ & 1 & 3 & & & & & & & & 11 & & & & & & & & & 4 & & & & & & & & \\
\hline 2. & $\begin{array}{l}\text { The people who play particular roles } \\
\text { in the project are provided with } \\
\text { appropriate training in project } \\
\text { management }\end{array}$ & & 4 & & & & & & & & 3 & 8 & & & & & & & & 4 & & & & & & & & \\
\hline 3. & $\begin{array}{l}\text { The enterprise has highly skilled } \\
\text { project managers }\end{array}$ & & & & & & & 1 & & 3 & & & & & & & 10 & & 1 & & & & & & & 4 & & \\
\hline 4. & $\begin{array}{l}\text { The people assigned to the projects are } \\
\text { competent to fulfil their given roles }\end{array}$ & & & & & & & 1 & 3 & & & & & & & & 5 & 1 & 5 & & & & & & & 4 & & \\
\hline 5. & $\begin{array}{l}\text { The enterprise has procedures and } \\
\text { mechanisms in place that ensure } \\
\text { professional project managers and } \\
\text { project team members }\end{array}$ & & & & & & & 1 & 3 & & & & & & & & 4 & 4 & 3 & & & & & & & 4 & & \\
\hline 6. & $\begin{array}{l}\text { The enterprise provides professional } \\
\text { development of project managers }\end{array}$ & & & & & & & 1 & 2 & 1 & & & & & & & 6 & 5 & & & & & & & & 3 & 1 & \\
\hline
\end{tabular}

Own elaboration. 
Table 5.

The results of research regarding the area of environment in mining service enterprises in Poland

\begin{tabular}{|c|c|c|c|c|c|c|c|c|c|c|c|c|c|c|c|c|c|c|c|c|c|c|c|c|c|c|c|c|}
\hline \multirow[b]{3}{*}{ No. } & \multirow[b]{3}{*}{ Question } & \multicolumn{9}{|c|}{ Small enterprises } & \multicolumn{9}{|c|}{ Medium enterprises } & \multicolumn{9}{|c|}{ Large enterprises } \\
\hline & & \multicolumn{9}{|c|}{ Answers } & \multicolumn{9}{|c|}{ Answers } & \multicolumn{9}{|c|}{ Answers } \\
\hline & & 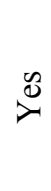 & 之 & $\begin{array}{l}\dot{0} \\
\overrightarrow{0} \\
z\end{array}$ & 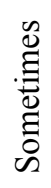 & $\frac{\lambda}{\sum^{\circ}}$ & 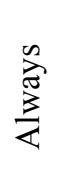 & $\stackrel{0}{\nu}$ & 之 & 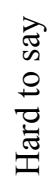 & $\stackrel{\infty}{\infty}$ & $\stackrel{\circ}{z}$ & $\begin{array}{l}\overline{0} \\
\dot{0} \\
z\end{array}$ & 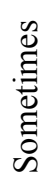 & 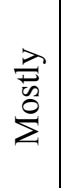 & 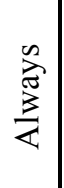 & $\stackrel{y}{2}$ & z & 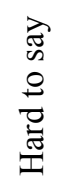 & $\stackrel{0}{2}$ & z & $\begin{array}{l}\dot{\bar{d}} \\
\overrightarrow{0} \\
\bar{z}\end{array}$ & 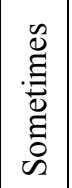 & 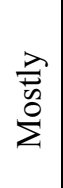 & $\sum_{i}^{\infty}$ & $\stackrel{\infty}{\infty}$ & z & 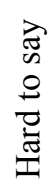 \\
\hline 1. & $\begin{array}{l}\text { Definitions of project aims } \\
\text { (except for time, cost and scope) } \\
\text { include clearly distinguished } \\
\text { strategic goals }\end{array}$ & & & 1 & 3 & & & & & & & & & 4 & 5 & 2 & & & & & & 1 & 3 & & & & & \\
\hline 2. & $\begin{array}{l}\text { The enterprise is aware of how } \\
\text { valuable the project is }\end{array}$ & & & & & & & 1 & & 3 & & & & & & & 10 & & 1 & & & & & & & 4 & & \\
\hline 3. & $\begin{array}{l}\text { The enterprise applies project } \\
\text { management to achieve the } \\
\text { organisation's business objectives }\end{array}$ & & & & & & & & & 4 & & & & & & & 9 & & 2 & & & & & & & 4 & & \\
\hline 4. & $\begin{array}{l}\text { The enterprise is well aware of } \\
\text { how valuable project } \\
\text { management is }\end{array}$ & & & & & & & 1 & 1 & 2 & & & & & & & 10 & & 1 & & & & & & & 4 & & \\
\hline 5. & $\begin{array}{l}\text { The enterprise has a well-defined } \\
\text { vision of project management }\end{array}$ & & & & & & & $\mathbf{1}$ & $\mathbf{1}$ & 2 & & & & & & & 9 & & 2 & & & & & & & 4 & & \\
\hline
\end{tabular}

Own elaboration. 
Table 6.

The results of research regarding the area of knowledge management in mining service enterprises in Poland

\begin{tabular}{|c|c|c|c|c|c|c|c|c|c|c|c|c|c|c|c|c|c|c|c|c|c|c|c|c|c|c|c|c|}
\hline \multirow[b]{3}{*}{ No. } & \multirow[b]{3}{*}{ Question } & \multicolumn{9}{|c|}{ Small enterprises } & \multicolumn{9}{|c|}{ Medium enterprises } & \multicolumn{9}{|c|}{ Large enterprises } \\
\hline & & \multicolumn{9}{|c|}{ Answers } & \multicolumn{9}{|c|}{ Answers } & \multicolumn{9}{|c|}{ Answers } \\
\hline & & $\stackrel{\infty}{\infty}$ & z & $\begin{array}{l}\overline{0} \\
\dot{0} \\
z\end{array}$ & $\begin{array}{l}\mathscr{0} \\
\stackrel{0}{\Xi} \\
\stackrel{0}{0} \\
\tilde{D}\end{array}$ & 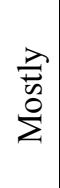 & $\sum_{\substack{i \\
\xi}}^{\infty}$ & $\stackrel{\infty}{\infty}$ & z & 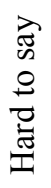 & $\stackrel{0}{2}$ & Z & $\begin{array}{l}\overline{0} \\
\dot{0} \\
\bar{z}\end{array}$ & 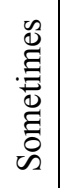 & 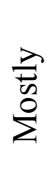 & 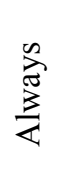 & $\stackrel{0}{2}$ & z & 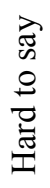 & $\stackrel{\infty}{\nu}$ & z & $\begin{array}{l}\overline{0} \\
\dot{0} \\
z\end{array}$ & 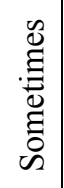 & $\begin{array}{l}\overrightarrow{\vec{D}^{2}} \\
\sum^{0}\end{array}$ & 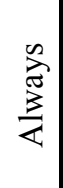 & $\stackrel{\infty}{2}$ & $\stackrel{\circ}{z}$ & 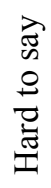 \\
\hline 1. & $\begin{array}{l}\text { The enterprise has a defined system of } \\
\text { cooperation and exchange of } \\
\text { information among project managers }\end{array}$ & & 4 & & & & & & & & 5 & 6 & & & & & & & & 3 & 1 & & & & & & & \\
\hline 2. & $\begin{array}{l}\text { The enterprise records the knowledge } \\
\text { and experience acquired during the } \\
\text { execution of individual projects }\end{array}$ & & & 1 & & 2 & 1 & & & & & & & & 6 & 5 & & & & & & & & 2 & 2 & & & \\
\hline 3. & $\begin{array}{l}\text { The enterprise employs procedures and } \\
\text { mechanisms that ensure that project } \\
\text { managers and project team members } \\
\text { have adequate knowledge and } \\
\text { experience }\end{array}$ & & & 3 & 1 & & & & & & & & & 1 & 4 & 6 & & & & & & & & 1 & 3 & & & \\
\hline 4. & $\begin{array}{l}\text { The enterprise is a community of people } \\
\text { interested in project management }\end{array}$ & & & & & & & & 2 & 2 & & & & & & & 6 & 1 & 4 & & & & & & & 2 & & 2 \\
\hline 5 . & $\begin{array}{l}\text { Intellectual capital is collected and } \\
\text { stored }\end{array}$ & & & & & & & & 3 & 1 & & & & & & & 9 & & 2 & & & & & & & 3 & & 1 \\
\hline 6. & $\begin{array}{l}\text { Intellectual capital is utilised in next } \\
\text { projects }\end{array}$ & & & & & & & & 2 & 2 & & & & & & & 8 & & 3 & & & & & & & 3 & & 1 \\
\hline
\end{tabular}

Own elaboration. 


\section{The area of the environment}

The research conducted shows that only $37 \%$ of enterprises define project objectives (except for time, cost and scope), which include clearly identified strategic objectives. Only $63 \%$ of medium-sized enterprises have such project objectives. $79 \%$ of the enterprises are conscious of the value of the project for the organisation. Only $75 \%$ of small enterprises are not aware of the value of the project. In $68 \%$ of the enterprises, project management is used to achieve the business objectives of the organisation; this is the case for $100 \%$ of large mining service enterprises. However, project management for business purposes is not used in all small mining service enterprises. In $79 \%$ of the researched mining service enterprises, there is a general awareness of the value of project management. Only $25 \%$ of small enterprises have such awareness. $73.6 \%$ of mining service enterprises have a defined vision of project management. There is no defined project management vision for $75 \%$ of small enterprises.

Project maturity in the area of project environment is diversified in mining service enterprises and has been assessed as follows:

- in small mining service enterprises at level 1 (Initial), as they do not have a management or organisational system to support project management,

- in medium mining service enterprises at level 2 (Standardisation), as these organisations have management and organisational systems that partially support project management,

- in large mining service enterprises at level 3 (Applications/Usage), where these systems are mainly used for project management.

\section{The area of knowledge management}

The conducted research shows that only $42 \%$ of mining service enterprises have a defined system of cooperation and flow of information among project managers. $45 \%$ of medium enterprises and $75 \%$ of large enterprises have a defined system. There is no such system in small mining service enterprises. In $94 \%$ of mining service enterprises, including all large and medium enterprises, and only $25 \%$ of small enterprises, the knowledge and experience gained during the execution of individual projects is recorded. In $73.6 \%$ of enterprises, procedures and mechanisms are applied that ensure that project managers and project team members have the appropriate knowledge and experience, while in no small enterprise are such procedures applied. In only $42 \%$ of mining service enterprises is there a community of people interested in project management. In small mining service enterprises, there is no such community. In medium enterprises, this is 50\%, and 55\% in large enterprises. In $63 \%$ of the researched enterprises, intellectual capital is gathered and stored. And only $57.8 \%$ of mining service enterprises ensure professional development of project managers, while this is $75 \%$ in large enterprises, $73 \%$ in medium enterprises and $0 \%$ in small enterprises. 
The project maturity of large mining service enterprises in the area of knowledge management was assessed at level 2, as standards are defined in these enterprises but are applied selectively. Unfortunately, small and medium mining service enterprises have no standards in knowledge management, and the maturity of project management in this area was assessed at level 1 (Initial).

The summary of the survey research, conducted with a view to determine the level of maturity in the project management of mining service enterprises in Poland, is shown in Table 7.

\section{Summary}

With regard to the results of the conducted survey research, the answers to the questions were obtained. The research results showed that large and medium-sized mining service enterprises usually have defined standards and tools for project management and apply them in practice. Furthermore, they develop systems for measuring the efficiency of project managers and have an appropriate organisational structure in place to support project management. Intellectual capital (knowledge and experience) is gathered, stored and used in further projects. However, there are no appropriate mechanisms in place to ensure the best possible use of this capital. Large and medium-sized enterprises mostly have a maturity level 2 or 3 for project management.

Small mining service enterprises are generally at the lowest level of project maturity, which means that they do not have defined standards and tools for project management, they do not have efficiency measurement systems for project managers, they do not have a proper organisational structure, and they do not gather and store the knowledge of project teams.

\section{Table 7.}

Assessment of the project maturity of mining service enterprises in Poland-research results

\begin{tabular}{|c|c|c|c|c|}
\hline & \multicolumn{4}{|c|}{ Area } \\
\hline $\begin{array}{l}\text { Mining service } \\
\text { enterprises }\end{array}$ & $\begin{array}{l}\text { Methods } \\
\text { and Tools }\end{array}$ & $\begin{array}{l}\text { Human } \\
\text { Resources }\end{array}$ & Environment & $\begin{array}{l}\text { Knowledge } \\
\text { Management }\end{array}$ \\
\hline Total & $\begin{array}{l}\text { LEVEL } 3 \\
\text { Applications/Usage }\end{array}$ & $\begin{array}{l}\text { LEVEL } 2 \\
\text { Standardisation }\end{array}$ & $\begin{array}{l}\text { LEVEL } 2 \\
\text { Standardisation }\end{array}$ & $\begin{array}{l}\text { LEVEL } 1 \\
\text { Initial }\end{array}$ \\
\hline Small enterprises & $\begin{array}{l}\text { LEVEL } 1 \\
\text { Initial }\end{array}$ & $\begin{array}{l}\text { LEVEL } 1 \\
\text { Initial }\end{array}$ & $\begin{array}{l}\text { LEVEL } 1 \\
\text { Initial }\end{array}$ & $\begin{array}{l}\text { LEVEL } 1 \\
\text { Initial }\end{array}$ \\
\hline $\begin{array}{l}\text { Medium } \\
\text { enterprises }\end{array}$ & $\begin{array}{l}\text { LEVEL } 3 \\
\text { Applications/Usage }\end{array}$ & $\begin{array}{l}\text { LEVEL } 2 \\
\text { Standardisation }\end{array}$ & $\begin{array}{l}\text { LEVEL } 2 \\
\text { Standardisation }\end{array}$ & $\begin{array}{l}\text { LEVEL } 1 \\
\text { Initial }\end{array}$ \\
\hline Large enterprises & $\begin{array}{l}\text { LEVEL } 3 \\
\text { Applications/Usage }\end{array}$ & $\begin{array}{l}\text { LEVEL } 3 \\
\text { Applications/Usage }\end{array}$ & $\begin{array}{l}\text { LEVEL } 3 \\
\text { Applications/Usage }\end{array}$ & $\begin{array}{l}\text { LEVEL } 2 \\
\text { Standardisation }\end{array}$ \\
\hline
\end{tabular}

Source: own elaboration. 


\section{References}

1. Grundy, T., Brown, L. (2002). Strategic Project Management-Creating Organizational Breakthroughs. Cornvall: Thomson.

2. http://sjsi.org/slowo/model-dojrzalosci/, 07.01.2018.

3. Juchniewicz, M. (2009). Dojrzałość projektowa organizacji. Warszawa: Biblioteka Project Managera.

4. Juchniewicz, M. (2009). Dojrzałość projektowa organizacji i jej zastosowanie w zarządzaniu. Przeglad Organizacji, 7-8.

5. Juchniewicz, M. (2016). Osiąganie doskonałości w realizacji projektów przy wykorzystaniu modelu dojrzałości projektowej. In: E. Trocki, E. Bukłaha, Zarzadzanie projektami wyzwania i wyniki badań. Warszawa: Wydawnictwo SGH.

6. Kerzner, H. (2005). Advanced Project Management. Gliwice: Helion.

7. Managing Successful Programmes (2007). Norwich: Office of Government Commerce, The Stationery Office.

8. Project Management Body of Knowledge (2008). Project Management Institute.

9. Schott, E., Campana, Ch. (2005). Strategisches Projektmanagement. Berlin-Heidelberg: Springer Verlag.

10. Spałek, S. (2013). Dojrzałość przedsiębiorstwa w zarzadzaniu projektami. Gliwice: Wydawnictwo Politechniki Śląskiej.

11. Spałek, S. (2015). Granice inwestycyjne zwiększania stopnia dojrzałości w zarządzaniu projektami. In: W.R. Knosala, Innowacje w zarzadzaniu i inżynierii produkcji, Tom I. Opole: Oficyna Wydawnicza Polskiego Towarzystwa Zarządzania Produkcją.

12. Spałek, S., Karbownik, A. (2014). Rekomendacje dla zwiększenia stopnia dojrzałości $\mathrm{W}$ zarządzaniu projektami w przedsiębiorstwach przemysłu maszynowego w Polsce. Przegląd Organizacji, 9.

13. Strojny, J. (2012). Innowacyjność i kreatywność w rozwiąywaniu problemów biznesowych. Rzeszów: Politechnika Rzeszowska.

14. Strojny, J. (2019). Orientacja procesowo-projektowa organizacji samorzadu lokalnego. Wymiary, poziomy dojrzałości, determinanty oraz efekty $w$ zakresie rozwoju lokalnego. Rzeszów: Oficyna Wydawnicza Politechniki Rzeszowskiej.

15. Wyrozębski, M., Juchniewicz, M., Matelski, W. (2012). Wiedza, dojrzałość, ryzyko w zarzadzaniu projektami. Wyniki badań. Warszawa: Oficyna Wydawnicza Szkoła Główna Handlowa. 